\title{
Work Health and Safety, Competitive Advantage, and Organisational Performance in Small Construction Firms: Research Proposal
}

\author{
Raed Eldejany ${ }^{1}$ \\ ${ }^{1}$ Director at All Facility Services P/L, New South Wales, Revesby, Australia \\ Correspondence: Raed Eldejany, Director at All Facility Services P/L, 11/172 Milperra Road, Revesby, New \\ South Wales, Australia. E-mail: raed@allfs.com.au
}

Received: December 20, 2016 Accepted: January 10, 2017 Online Published: January 25, 2017

doi:10.5539/jms.v7n1p11 URL: http://dx.doi.org/10.5539/jms.v7n1p11

\begin{abstract}
Research into small firms has expanded over recent years, yet one field where insight is still limited is Work Health and Safety (WHS) especially in the high risk construction industry. The main objective of this research proposal is to provide the foundation for a potential future study that explores the impact of WHS on developing a competitive advantage and improving organisational performance from the perspective of the owner-managers of small Australian construction firms using a qualitative multiple case design. This research proposal investigates a sample of four small construction firms from the same industry therefore the findings can't be generalised to other work environments, which a limitation to the proposed study.
\end{abstract}

Keywords: competitive advantage, construction, small firm, organizational performance, qualitative research proposal, work health and safety

\section{Introduction}

\subsection{Research Problem}

In 2014-15, according to the Australian Bureau of Statistics (ABS) (2016), there were 345,479 active construction firms that operated in the State of New South Wales, Australia, $96 \%$ of which were small firms that employed less than 20 employees. According to the Australian Parliament (2015), small firms in all industries contributed $\$ 343.4$ billions to the Australian economy in 2013-2014, $14.7 \%$ of which was contributed by small construction firms second after the rental, hiring and real estate services.

In 2010-11, Safe Work Australia (2013) ranked the construction industry as the fourth largest incidence rates of serious injury at a rate of 18.7 claims per 1000 employees just 3\% below Transport, Agriculture and Manufacturing, and had the third largest fatality rate after Agriculture and Transport. Labourers and tradespeople constituted two of the top three highest injury rates by occupation. The fact that small firms constitute $96 \%$ of the construction industry means that small firms are faced with the problem of having the highest rate of accidents in the construction industry. This situation according to Koper, Moller, \& Zwetsloot (2009) impacts negatively on the physical, mental and social wellbeing of employees, increase cost of production, make firms less competitive, and reduce small construction firms' profitability, growth, and contribution to the Australian economy. O'Toole (2002) argues that management commitment to WHS plays a key role in the successful development and implementation of safety programs and improving safety performance, which has a positive relationship with competitive advantage and overall organisational performance (Rechenthin, 2004). Therefore, it is important to investigate this relationship from the perspective of owner-managers.

\subsection{Objective of the Research Proposal}

The objective of this research proposal is to provide the foundation for a potential future study that explores the impact of WHS on developing a competitive advantage and improving organisational performance from the perspective of the owner-managers of small Australian construction firms.

\section{Literature Review}

Research suggests that small firms don't manage WHS risks as effectively as larger firms (Holmes, Lingard, Yesilyurt, \& DeMunk, 1999) due to the lack of skilled resources required to deal with safety issues as well as the cost involved in the development and implementation of safety systems (Champoux \& Brun, 2003; Wilson, 2000). Recent research indicates that small firm construction industry managers comprehend risk in terms of 
issues internal to workers, such as lack of knowledge and attention (Holmes et al., 1999), and conceptualize risk control as an obligation of the individual rather than the firm (Glendon, Clarke, \& McKenna, 2006; Lingard \& Holmes, 2001). This conceptualization poses difficulties for the prevention of work accidents, injuries and diseases, which contribute to the higher incidence of occupational injury in small construction firms (McVittie, Banikin, \& Brocklebank, 1997). Therefore, Fruhen, Mearns, \& Kirwan (2014) propose that management need to improve their problem-solving abilities and perception of others through focused safety training and guidance.

Researchers (Beus, Payne, Bergman, \& Arthur, 2010; Cohen, 1977; O’Toole, 2002) argue that management commitment to WHS plays a key role in the successful development and implementation of safety programs, which positively influence workers' understanding of their rights, responsibilities and obligations under the WHS laws leading to positive safety performance. A number of studies (Lamm, Massey, \& Perry, 2007; Muniz, Peon, \& Ordas, 2009; Rechenthin, 2004) found a positive relationship between organisational safety performance, competitive advantage and overall organisational performance.

According to Smallman (2001) there is a well-established safety research that covers the perceptions and attitudes of employees toward WHS, which led to a wealth of literature that is more in favour of understanding how employees perceive WHS. This is in line with Quinlan, Bohle, \& Lamm (2010) suggestion that early psychological studies in WHS focused on employees in terms of cause and prevention rather than the working environment. Although understanding this is essential, there is much less literature that reflects top management perception of WHS (Hayes, Perander, Smecko, \& Trask, 1998). The little that exists is limited to the development of safety management systems and their impact on safety performance, as well as management support for behaviour based approaches to WHS (Cox \& Cox, 1991; Fuller, 1999; Hine, Lewko, \& Blanco, 1999; Simard \& Marchand, 1995; Thompson, Hilton, \& Witt, 1998), and most of this work focus on employee's perception of management obligations (Smallman, 2001).

Studies by (Hasle, Limborg, Kallehave, Klitgaard, \& Andersen, 2011; Smallman, 2001) argue that little attention has been given to research WHS in small construction firms, which suggests that our knowledge and understanding of owner managers as key actors and their perception of WHS is rather thin. In addition, the impact of WHS on the commercial aspects of business, such as strategic management, competitive advantage and organisational performance has also received little consideration in the literature (Smallman, 2001; Zanko \& Dawson, 2012).

Although Smallman \& John (2001) claim that there is no substantial literature that directly links WHS performance with competitive advantage, other literature (Kjellen, Boe, \& Hagen, 1997; Rechenthin, 2004) concluded a positive relationship between safety performance and sustainable competitive advantage in construction firms. Also, Muniz, Peon, Camilo, \& Vazquez-Ordas (2009) found that quality WHS reduces accidents, increase employee productivity and motivation, as well as improve firm reputation, which are all assets that can provide firms with a sustainable competitive advantage.

Research in corporate social performance (CSP) measurement (Carroll \& Buchholtz, 2012) presents perhaps the best potential for relating WHS issues with competitive advantage and organisational performance. In particular, the assessment of internal social performance, which centres on employee WHS and personnel development, is crucial in establishing the relationship (Swanson, 1999; Wood \& Jones, 1996). CSP research is mainly based on the stakeholder theory of organisations, which states that by complying with ethical principles such as employee safety and well-being, firms can develop significant competitive advantage (Freeman, 1984; Jones, 1995) and consequently improve organisational performance (Douglas \& Douglas, 2010). However, this can only be achieved when WHS form a major part of the firm's objectives, otherwise it is destined to take the back seat to more important commercial matters (Dawson, Willman, Clinton, \& Bamford, 1988).

\subsection{Research Questions}

The above literature review highlights WHS in small construction firms as an area within business that received little attention in literature, specifically from the perspective of owner managers and as a potential source for developing competitive advantage and improving organisational performance. Therefore, understanding how owner managers perceive WHS in their small construction firms may provide insight into the impact of safety performance on developing a competitive advantage and improving business performance, which leads to the following research questions:

1) How do owner managers of small Australian construction firms perceive WHS?

2) How do owner managers of small Australian construction firms perceive their WHS behaviour toward their employees? 
3) How do owner managers of small Australian construction firms perceive their WHS behaviour toward their employees to impact on building a competitive advantage and improving business performance?

4) How do employees in small Australian construction firms perceive their owner managers' behaviour toward WHS?

\section{Method}

As highlighted above, owner managers of small construction firms are an under investigated phenomenon (Smallman, 2001). An interpretive qualitative approach will allow for the deep understanding of the phenomenon, which can be achieved by interpreting those who experience it (Lofland \& Lofland, 1996). An interpretive paradigm recognises the importance of the subjective human creation of meaning (Baxter \& Jack, 2008), and is based on the belief that the inquirer and the inquired are interconnected in such a way that the findings of the study are the actual creation of the inquiry process (Al Zeera, 2001). This is in contrast with the functionalist paradigm, which maintains the belief that it is conceivable for an observer to exteriorize the reality under study, and remain separated from it (Al Zeera, 2001).

\subsection{Research Design}

Case study research is criticized for being conceptual that lacks rigour and generalizability (Yin, 2009). Nevertheless, qualitative case study design allows responding to the complexity, constantly changing and partially predictable business environment as well as making contribution to both theory and practice (Gummesson, 2007). A qualitative case study, using multiple data sources, presents an opportunity to gain an in-depth understanding of how owner managers of small construction firms interact with and manage the health and safety needs of their working environment including employees (Romano, 1989). This ensures that the phenomenon is explored through a variety of lenses allowing for multiple aspects of the phenomenon to be uncovered and understood (Baxter \& Jack, 2008), which is relevant in addressing the research questions of this study. Data collection is through in-depth interviews, participant observations and documents.

A case study is deemed appropriate to address the research questions because the study focuses on answering "how" questions, also a case study will help to understand the contextual conditions and their impact on the safety behaviour of owner managers (Yin, 2009). Context within which owner managers operate plays a key role in gaining a deep understanding of their behaviour, therefore detaching them from their organisational setting would make it difficult to acquire insight into their behaviour toward WHS (Yin, 2009).

A multiple case design is employed, each of which is considered a separate unit of analysis. Each case is analysed separately and then act as a contributor to the identification of replications and differences to other cases (Yin, 2009). The unit of analysis for each case is the owner manager. Each case is represented by a small construction firm located in New South Wales (NSW) Australia, thus the case study is bounded by context (Miles \& Huberman, 1994), activity (Stake, 1995), and by place (Creswell, 2003). This will ensure better control of the research scope (Baxter \& Jack, 2008).

The rationale behind using a multiple case design as Yin (2009) explains is that it allows examining several cases in order to understand the similarities and differences between them and predict literal or theoretical replication. This means that the findings of a multiple case study can be used to confirm, challenge or extend the propositions made by stakeholder theory via insight gleaned from the different units of analysis (Tellis, 1997). Furthermore, the evidence from a multiple case designis considered more robust and reliable compared to a single case design (Yin, 2009).

\subsection{Sampling}

Qualitative sampling aims to gain improved understanding of complex human issues, in contrast with quantitative research which aims to produce a representation of the population (Marshall, 1996). Four privately owned small construction firms are selected purposively from the researcher's own contact list. The four firms are based in Sydney Australia, specialise in general building work, employ between 5 and 19 staff including the owner manager, and have been in operation for 5 to 6 years.

Although random sampling offers the best opportunity to generalize the findings to the population, purposive sampling provides the most effective way of developing an understanding of the current phenomenon under study (Marshall, 1996). In addition, purposive sampling attracts a possible element of bias, yet it is this inherent bias of the method that adds to its efficiency and robustness when tested against random probability sampling (Tongco, 2007).

Purposive sampling is fundamental to the production of quality data. Each firm is selected based on the industry knowledge and expertise of its owner manager, thus provide richer insights and contribute to the theoretical 
understanding of the social phenomenon. The initial decision is that four firms from the same market segment are adequate, yet a decision can be made if more firms are required after the initial process of data analysis.

\subsection{Data Collection Methods}

\subsubsection{Semi-Structured Interviews}

An interview is a highly effective method for collecting rich, empirical data, especially when the phenomenon of interest can't comprehensively be understood through observation (Eisenhardt \& Graebner, 2007). It allows access to a wide variety of people and situations and can be directed to focus on the phenomenon under study and its associated research questions (Bryman \& Bell, 2011).

A semi-structured interview method is considered appropriate because it provides some structure that ensures cross-case comparability when using a multiple case study design (Bryman \& Bell, 2011). It is an informal and flexible method because it allows departure from any schedule or guide that is being used, whereby new questions can arise as a result of significant issues that emerge in the course of the interview, which help adjusting the emphases in the research and producing rich and detailed answers that reflects the participants' view of their social world and that touches on the research questions and key topics (Bryman \& Bell, 2011).

An interview guide is developed with a fairly clear focus on gaining interviewee's own perspectives on areas related to the research questions. A copy of the interview guide is offered to interviewee's on request which can strengthen the dependability of the research (Bryman \& Bell, 2011).

Gaining access to the firms is conducted by sending an introductory letter to the owner manager enclosing a short outline of the nature and purpose of the project and an indication of how the findings might be useful to the participants and their firms. A telephone call is made a few days after receipt of the introductory letter to deal with any queries the owner-manager has.

The qualitative methodology is a natural approach, where participants are studied in their natural settings rather than in isolation (Marshall, 1996). Therefore, the interviews are conducted at the firms' premises and working sites. In each firm, six interviewees including the owner manager are targeted with the goal of gaining comprehensive understanding of owner managers' safety behaviour within their organisational setting, as well as supporting the credibility of the findings through triangulation (Golafshani, 2003).

Moreover, each interviewee is to complete a face sheet including information such as name, age, years of employment, and industry expertise. This information can be used to contextualise participant responses (Bryman \& Bell, 2011).

\subsubsection{Participant Observation}

Participant observation is considered one of the main principles of qualitative research, whereby researchers are in a better position for gaining a foothold on social reality, which allow them to establish a link between behaviour and social setting (Bryman \& Bell, 2011).

A complete observer role is adopted due to the risky nature of construction sites, and the possible dangers the researcher might be exposed to as a result of participation. Although a full observer carries the risk of failing to understand situations or certain participant behaviours, the semi-structured interviews provide an avenue for clarifying any unclear situations or behaviours (Handley, 2008).

Observations take place during participants' daily work routines, site safety meetings (Tool Box Meetings), safety site inspections, and any planned safety meetings with the owner manager. Access to the various sites and safety meetings is organised through the owner managers and site supervisors to prevent any disruptions to work.

Clear and detailed summary of events and participant behaviour are written down in order to match the observations with the purpose of the research. In other words, this complete observer or structured method is guided by prior theory and literature (Handley, 2008), which help the researcher to handle the possible large quantity of ideas and incoherent impressions that could be generated.

\subsubsection{Documents}

Document analysis is a systematic process particularly applicable to qualitative case studies (Stake, 1995), during which contents are reviewed, evaluated, and interpreted (Bowen, 2009) in order to extract meaning, develop understanding and empirical knowledge (Corbin \& Strauss, 2008). It is used in combination with interviews and participant observation as a mean of triangulation (Golafshani, 2003). Document analysis is considered a very important tool for researchers, because it could help them identify further questions that need to be asked during interviews and situations that require further observation (Bowen, 2009). 
Safety minutes of meeting documents are collected and analysed because they can assist in revealing issues relevant to the research questions, such as owner manager and employee commitment to WHS through their regular attendance to safety meetings, the level of participation among employees and any possible disputes. In addition, the researcher seeks to analyse any available safety performance reports issued by existing customers. Examining these documents hermeneutically can illuminate the kinds of issues that the firms emphasise in their meetings and the kind of ways in which the issues are addressed (Bryman \& Bell, 2011).

\subsubsection{Recording Data}

Interview data are tape recorded, after seeking approval from the interviewees, in order to eliminate the possibility of memory failure, and to allow the interviewer to focus on the interview itself, whereby capturing as much data as possible for later analysis (Bryman \& Bell, 2011). In addition, notes are written down after completing each interview to reflect on the interviewee behaviour, the social setting and the researcher own perception.

It might not be necessary to hide taking notes during participant observation given that the observations are conducted overtly. However, employee knowledge that they are being observed may make them behave less naturally. Therefore, the researcher has to behave carefully in order to help participants become more familiar with the researcher's presence, and become less obtrusive to participants (Bryman \& Bell, 2011).

A daily journal is used by the researcher to collect and refine ideas and beliefs, which in conjunction with field notes, act as a way for the researcher to contemplate on their own possible biases during the process of data gathering, thus achieve a more comprehensive and credible understanding of the data collected (Janesick, 1999).

\subsubsection{Ethical Implications}

This research uses semi-structured interviews, participant observations and record collections as methods for collecting data. Participants have the right to give informed consent regarding their participation in the research study. The researcher informs the participants of the purpose of the study, what information is required, how it is used, in addition to the implications for them as participants (Beauchamp \& Childress, 2001). A confidentiality agreement is signed by the researcher to guarantee that the privacy of participants is respected by ensuring that their identities and responses are not revealed, and that the data records of participants and firms are maintained confidential (Bryman \& Bell, 2011). Access to any proprietary, intellectual property, and copyright aspects of documents is organised through the owner manager.

\section{Data Analysis}

In order to generate comprehensive and valuable insight into the safety behaviour of owner managers of small construction firms, both standalone and cross-case analysis is conducted. The NVivo software is used to store, manage, and interrogate the data collected as well as facilitate the process of coding, category construction, pattern and relationship finding, as well as theory testing (Bryman \& Bell, 2011). Codes are derived from the data collected during interviews, observations and document examination. Furthermore, data is examined against the literature to notice any convergence and divergence, which is critical to confirming existing theory (Tellis, 1997). Journal entries and research memos are examined against any political, cultural or social biases that might have affected the research approach (Bryman \& Bell, 2011).

Furthermore, the researcher takes all precautions to ensure that the participants are in no way directly harmed or adversely affected as a result of their participation in the research (Burns \& Grove, 1999). All precautions are taken to ensure that both the researcher and participants are not subjected to any harm while carrying out observations taking into consideration the risky nature of the working environment.

\section{Conclusion}

The main objective of this research proposal is to provide the foundation for a potential future study that explores the impact of WHS on developing a competitive advantage and improving organisational performance from the perspective of the owner-managers of small construction firms using multiple case design. A positive relationship between WHS and competitive advantage and organisational performance confirm the stakeholder theory, which states that by complying with ethical principles such as employee safety and well-being, firms can develop significant competitive advantage (Freeman, 1984; Jones, 1995) and improve organisational performance (Douglas \& Douglass, 2010). Thus, this research proposal can bolster the business case for WHS in small construction firms by encouraging management commitment and approval for investment in WHS. The research proposal can also demonstrate that WHS is not simply an issue of doing the right thing or avoiding costs associated with lost-time injuries and related expenses, but it can lead to reducing accidents and absenteeism as well as increasing productivity and job satisfaction (Willis, Brown, \& Prussia, 2012). 
It is recommended in future research to select samples from different industries, which can provide an insight if WHS is equally advantageous as a strategic choice in every industry (Rechenthin, 2004). In addition, the use of focus groups in future research can provide further insight to this study because it allows for selecting a larger sample of owner managers, which give participants the opportunity to probe each other's and further elicit a wide variety of views in relation to WHS (Bryman \& Bell, 2011).

\section{References}

Al Zeera, Z. (2001). Wholeness and holiness in education: An Islamic perspective. Herndon, VA: International Institute of Islamic Thought.

Australian Bureau of Statistics. (2016). Counts of Australian Businesses, including Entries and Exits, Jun 2011 to Jun $2015 . \quad$ Retrieved from http://www.abs.gov.au/ausstats/abs@.nsf/Latestproducts/8165.0Media\%20Release1Jun\%202011\%20to\%20 Jun $\% 202015$ ? opendocument\&tabname $=$ Summary\&prodno $=8165.0 \&$ issue $=J u n \% 202011 \% 20$ to $\% 20 J u n \% 20$ $2015 \&$ num $=\&$ view $=$

Australian Parliament. (2015). Statistical snapshot: small business contribution to economic performance in Australia. Retrieved from http://www.aph.gov.au/About_Parliament/Parliamentary_Departments/Parliamentary_Library/pubs/rp/rp15 16/Perform

Baxter, P., \& Jack, S. (2008). Qualitative case study methodology: Study design and implementation for novice researchers. The Qualitative Report, 13(4), 544-559. Retrieved from http://nsuworks.nova.edu/tqr/vol13/iss4/2/

Beauchamp, T. L., \& Childress, J. F. (2001). Principles of biomedical ethics (5th ed.). New York: Oxford University Press.

Beus, J. M., Payne, S. C., Bergman, M. E., \& Arthur Jr., W. (2010). Safety climate andinjuries: an examination of theoretical and empirical relationships. Journal of Applied Psychology, 95, 713-727. https://doi.org/10.1037/a0019164

Bowen, G. (2009). Document analysis as a qualitative research method. Qualitative Research Journal, 9(2), 27-40. http://dx.doi.org/10.3316/QRJ0902027

Bryman, A., \& Bell, E. (2011). Business research methods (3rd ed.). New York: Oxford University Press.

Burns, N., \& Grove, S. (1999). Understanding nursing research (2nd ed.). Philadelphia: WB Saunders.

Carroll, A. B., \& Buchholtz, A. K. (2012). Business \& society: Ethics, sustainability, and stakeholder management (8th ed.). Mason Ohio: South-Western Cengage Learning.

Champoux, D., \& Brun, J. (2003). Occupational health and safety management in small size enterprises: An overview of the situation and avenues for intervention and research. Safety Science, 41(4), 301-318. http://dx.doi.org/10.1016/S0925-7535(02)00043-7

Cohen, A. (1977). Factors in successful occupational safety programs. Journal of Safety Research, 9(4), 168-178. Retrieved from http://www.sciencedirect.com/science/journal/00224375

Corbin, J., \& Strauss, A. (2008). Basics of qualitative research: Techniques and procedures for developing grounded theory (3rd ed.). Thousand Oaks, CA: Sage. https://doi.org/10.4135/9781452230153

Cox, S. J., \& Cox, T. R. (1991). The structure of employee attitudes to safety. Work and Stress, 5, 93-106. http://dx.doi.org/10.1080/02678379108257007

Creswell, J. (2003). Research design: Qualitative, quantitative, and mixed methodsapproaches (2nd ed.). Thousand Oaks, CA: Sage.

Dawson, N., Willman, P., Clinton, A., \& Bamford, M. (1988). Safety at work-The limits of self-regulation. Cambridge: Cambridge University Press.

Douglas, A., \& Dougas, J. (2010). Differentiation for competitive advantage in a small family business. Journal of Small Business and Enterprise Development, 17(3), 371-386. http://dx.doi.org/10.1108/14626001011068680

Eisenhardt, K. M., \& Graebner, M. E. (2007). Theory building from cases: Opportunities and challenges. Academy of Management Journal, 50(1), 25-32. https://doi.org/10.5465/AMJ.2007.24160888

Freeman, R. E. (1984). Strategic management: A stakeholder approach. London: Pitman. 
Fruhen, L. S., Mearns, K. J., \& Kirwan, B. (2014). Skills, knowledge and senior managers' demonstrations of safety commitment. Safety Science, 69, 29-36. http://dx.doi.org/10.1016/j.ssci.2013.08.024

Fuller, C. W. (1999). An employee management consensus approach to continuous improvement in safety management. Employee Relations, 21, 405-417. http://dx.doi.org/10.1108/01425459910285528

Glendon, A., Clarke, S., \& McKenna, E. (2006). Human Safety and Risk Management (2nd ed.). Boca Raton, FL: CRC Press (Taylor \& Francis Group). https://doi.org/10.1201/9780849330902

Golafshani, N. (2003). Understanding reliability and validity in qualitative research. The Qualitative Report, 8(4), 597-607. Retrieved from http://www.nova.edu/ssss/QR/QR8-4/golafshani.pdf

Gummesson, E. (2007). Case study theory: Research and network birds of a feather. Qualitative Research in Organizations and Management: An International Journal, 2(3), 226-248. http://dx.doi.org/10.1108/17465640710835373

Handley, K. (2008). Interviewing. In R. Thorpe \& R. Holt (Eds.), The SAGE dictionary of qualitative management research (pp. 143-144). London, UK: Sage Publications Ltd.

Hasle, P., Limborg, H., Kallehave, T., Klitgaard, C., \& Andersen, T. (2011). The working environment in small firms: Responses from owner-managers. International Small Business Journal, 30(6), 622-639. https://doi.org/10.1177/0266242610391323

Hayes, B. E., Perander, J., Smecko, T., \& Trask, J. (1998). Measuring perceptions of workplace safety: Development and validation of the work safety scale. Journal of Safety Research, 29, 145-161. http://dx.doi.org/10.1016/S0022-4375(98)00011-5.

Hine, D. W., Lewko, J., \& Blanco, J. (1999). Alignment to workplace safety principles: An application to mining. Journal of Safety Research, 30, 173-185. https://doi.org/10.1016/S0022-4375(99)00012-2

Holmes, N., Lingard, H., Yesilyurt, Z., \& DeMunk, F. (1999). An exploratory study of meanings of risk control for long term and acute effect occupational health and safety risks in small business construction firms. Journal of Safety Research, 30, 251-261. https://doi.org/10.1016/S0022-4375(99)00020-1

Janesick, V. (1999). Journal about journal writing as a qualitative research technique: History, issues, and reflections. Qualitative Inquiry, 5(4), 505-524. https://doi.org/10.1177/107780049900500404

Jones, T. M. (1995). Instrumental stakeholder theory: A synthesis of ethics and economics. Academy of Management Review, 20(2), 404-437. Retrieved from http://www.jstor.org/stable/258852

Kjellen, U., Boe, K., \& Hagen, L. (1997). Economic effects of implementing internal control of health, safety and environment: A retrospective case study of an aluminium plant. Safety Science 27, 99-114. http://dx.doi.org/10.1016/S0925-7535(97)00066-0

Koper, B, Moller, K., \& Zwetsloot, G. (2009). The occupational safety and health scorecard-A business case example for strategic management. Scandinavian Journal of Work, Environment \& Health, 35(6), 413-420. https://doi.org/10.5271/sjweh.1361

Lamm, F., Massey, C., \& Perry (2007). Is there a link between Workplace Health and Safety and Firm Performance and Productivity? New Zealand Journal of Employment Relations (Online), 32(1), 72-86. Retrieved from http://search.informit.com.au/documentSummary;dn=135846714466567;res=IELBUS

Lingard, H., \& Holmes, N. (2001). Understandings of occupational health and safety risk control in small business construction firms: barriers to implementing technological controls. Construction Management and Economics, 19, 217-226. http://dx.doi.org/10.1080/01446190010002570

Lofland, J., \& Lofland, L. (1996). Analysing social settings (3rd ed.). Belmont, CA: Wadsworth.

Marshall, M. (1996). Sampling for qualitative research. Family Practice Oxford University Press, 13(6), 522-525. https://doi.org/10.1093/fampra/13.6.522

McVittie, D., Banikin, H., \& Brocklebank, W. (1997). The effect of firm size on injury frequency in construction. Safety Science, 27, 19-23. https://doi.org/10.1016/S0925-7535(97)00048-9

Miles, M. B., \& Huberman, A. M. (1994). Qualitative data analysis: An expanded sourcebook (2nd ed.). Thousand Oaks, CA: Sage.

Muniz, B., Peon, J., \& Vazquez-Ordas, C. (2009). Relation between occupational safety management and firm performance. Safety Science, 47, 980-991. http://dx.doi.org/10.1016/j.ssci.2008.10.022

O'Toole, M. F. (2002). The relationship between employees' perceptions of safety and organizational culture. 
Journal of Safety Research, 33, 231-243. https://doi.org/10.1016/S0022-4375(02)00014-2

Quinlan, M., Bohle, P., \& Lamm, F. (2010). Managing Occupational Health and Safety: A Multidisciplinary Approach (3rd ed.). South Yarra: Palgrave MacMillan.

Rechenthin, D. (2004). Project safety as a sustainable competitive advantage. Journal of Safety Research, 35, 297-308. https://doi.org/10.1016/j.jsr.2004.03.012

Romano, C. (1989). Research Strategies for Small Business: A case study approach. International Small Business Journal, 7(4). 35-43. https://doi.org/10.1177/026624268900700403

Safe Work Australia. (2013). Key Work Health and Safety Statistics, Australia, 2013. Retrieved from http://www.safeworkaustralia.gov.au/sites/SWA/about/Publications/Documents/758/Key-WHS-Statistics-20 13.pdf

Simard, M., \& Marchand, A. (1995). A multilevel analysis of organizational factors related to the taking of safety initiatives by work groups. Safety Science, 21, 113-129. http://dx.doi.org/10.1016/0925-7535(95)00050-X

Smallman, C. (2001). The reality of revitalizing health and safety. Journal of Safety Research, 32, 391-439. https://doi.org/10.1016/S0022-4375(01)00065-2

Smallman, C., \& John, C, (2001) British directors' perspectives on the impact of health and safety on corporate performance. Safety Science, 38, 227-239. http://dx.doi.org/10.1016/S0925-7535(01)00003-0

Stake, E. (1995). The art of case study research. Thousand Oaks, CA: Sage.

Swanson, D. L. (1999). Towards an integrated theory of business and society: A research strategy for corporate social performance. Academy of Management Review, 24(3), 506-521. Retrieved from http://www.jstor.org/stable/259139

Tellis, W. (1997). Application of a case study methodology. The Qualitative Report, 3(3). Retrieved from http://nsuworks.nova.edu/tqr/vol3/iss3/1

Thompson, R. C., Hilton, T. F., \& Witt, L. A. (1998). Where the safety rubber meets the shop floor: A confirmatory model of management influence on workplace safety. Journal of Risk Research, 29, 15-24. https://doi.org/10.1016/s0022-4375(97)00025-x

Tongco, M. (2007). Purposive sampling as a tool for informant selection. Ethnobotany Research \& Applications, 5, 147-158. https://doi.org/10.17348/era.5.0.147-158

Willis, G., Brown, K., \& Prussia, G. (2012). Does employee safety influence customer satisfaction? Evidence from the electric utility industry. Journal of Safety Research, 43, 389-396. http://dx.doi.org/10.1016/j.jsr.2012.10.003

Wilson, J., Joe, M., \& Koehn, E. (2000). Safety management: Problems encountered and recommended solutions. $\begin{array}{lllll}\text { Journal of Construction Engineering and Management, } & \text { 126(1), }\end{array}$ http://dx.doi.org/10.1061/(ASCE)0733-9364(2000)126:1(77)

Wood, D. J., \& Jones, R. E. (1996). Research in corporate social performance: What have we learned? In D. F. Burlingame \& D. R. Young (Eds.), Corporate philanthropy at the crossroads. Bloomington Indiana: Indiana University Press.

Yin, K. (2009). Case study research: Design and methods (4th ed.). Thousand Oaks, CA: Sage.

Zanko, M., \& Dawson, P. (2012). Occupational health and safety management in organizations: A review. $\begin{array}{llll}\text { International Journal of } & \text { Management }\end{array}$ https://doi.org/10.1111/j.1468-2370.2011.00319.x

\section{Copyrights}

Copyright for this article is retained by the author(s), with first publication rights granted to the journal.

This is an open-access article distributed under the terms and conditions of the Creative Commons Attribution license (http://creativecommons.org/licenses/by/4.0/). 